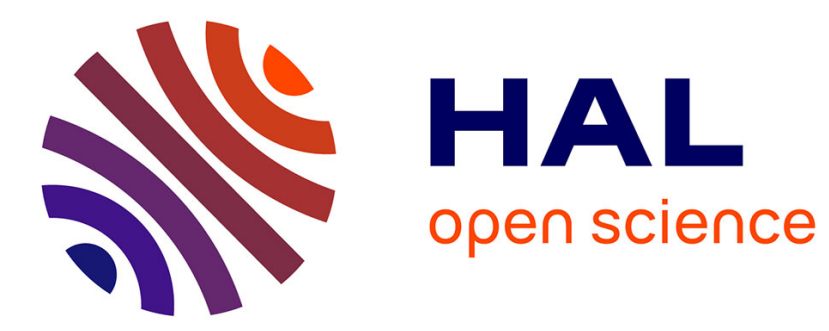

\title{
Complex verbs and dependency strategies in Nêlêmwa (New Caledonia)
}

\author{
Isabelle Bril
}

\section{To cite this version:}

Isabelle Bril. Complex verbs and dependency strategies in Nêlêmwa (New Caledonia). Complex predicates in Oceanic languages: Studies in the dynamics of binding and boundness, Mouton de Gruyter, pp.167-198, 2004, Empirical Approaches to Linguistic Typology. halshs-00006154v2

\section{HAL Id: halshs-00006154 \\ https://shs.hal.science/halshs-00006154v2}

Submitted on 11 Jun 2013

HAL is a multi-disciplinary open access archive for the deposit and dissemination of scientific research documents, whether they are published or not. The documents may come from teaching and research institutions in France or abroad, or from public or private research centers.
L'archive ouverte pluridisciplinaire HAL, est destinée au dépôt et à la diffusion de documents scientifiques de niveau recherche, publiés ou non, émanant des établissements d'enseignement et de recherche français ou étrangers, des laboratoires publics ou privés. 


\title{
Complex verbs and dependency strategies in Nêlêmwa (New Caledonia)
}

\author{
Isabelle Bril
}

\begin{abstract}
This paper analyses the various types of serial and complex verbs and the criteria that help restrict this phenomenon in Nêlêmwa. Complex verbs belong to three main types involving various types of verb and different hierarchies: (i) timeiconic, co-ranking active verbs; (ii) asymmetric verbs expressing adverbial modification or aspectual and modal specification; (iii) semi-grammaticalized verb strings with argument-expanding or conjunctive functions. This paper also investigates the role of complex verbs in a typology of clause-linkage and assesses the syntactic, semantic and discourse differences between one-clause and multiclause strategies: i.e. between complex verbs and syndetic or asyndetic coordinate or subordinate VPs and clauses. It also assesses the semantic notions which are conceptualized as complex predicates rather than as interdependent clauses.
\end{abstract}

\section{Introduction}

Nêlêmwa is one of the twenty-eight Kanak languages of New Caledonia, it is spoken by approximately a thousand speakers in the Far North of the Mainland. These languages belong to the Remote Oceanic subgroup of the Austronesian family. Here is a brief overview of the syntactic organization and typological features of Nêlêmwa.

Nêlêmwa has a split constituent order and split accusative-ergative casemarking system varying with argument category. Personal pronouns, which only refer to human entities (inanimates are zero-marked) have an accusative system, while nominal arguments are case-marked as ergative or absolutive; the ergative case-markers are (e)a (for animate agents) and $r u$ (for inanimate agents) and the absolutive case is zero. The neutral order is sVo with subject and object pronouns referring to human entities (otherwise $\varnothing \mathrm{V})$, whereas nominal arguments come after the predicate, either as vS 
(where [S] is the absolutive nominal argument of an intransitive verb) or VOA (where $\mathrm{O}$ stands for the second argument/patient and A for the agent of a transitive verb). The subject index cross-references the postverbal nominal prime argument (if human), irrespective of its absolutive or ergative case-marking and agrees in number with it, thus (s)VS, or (s)VOA; whereas the object pronoun does not occur with the nominal second argument.

\section{2. "Nuclear layer" serial constructions $[(\mathbf{s}) \mathrm{Vv}(0)]$ in Nêlêmwa}

Serial constructions in Oceanic languages are generally described as belonging to three main types - nuclear, core and adjunct serialization ${ }^{1}-$ according to the level and type of nexus (see, Bril introduction, this vol.). Some languages display several types varying with verbal category ${ }^{2}$ or syntactic function.

New Caledonian languages differ in their constituent order, SVO, vos, and sometimes mixed SVO and VOS order according to tense-aspect; however they all display the nuclear type of serial construction, i.e. with contiguous verbs [sVVo]. They are thus counterexamples to Foley and Olson's (1985) generalization that "nuclear layer" serialization is mostly found in SOV languages, while SVO languages have predominant core layer serialization. In Nêlêmwa, serial verb constructions have one single primeargument and one single patient $[\mathbf{s V V}(\mathrm{V})(\mathbf{o})] ;[\mathbf{s V} \mathbf{s V}]$ patterns would constitute two independent clauses with a pause inbetween, not a serial construction. Thus, a verb string does not necessarily constitute a serial verb construction, and a finer-grained analysis is required. Different terms will be used to refer to various types of verb strings: serial verb construction will only be used for co-ranking constructions that follow the criteria and rules listed in 2.1 and 2.4 below; a complex predicate will refer to an asymmetric verb string comprising a verbal head and a verbal adjunct (see 2.7 and 2.8) or to an Aktionsart or modal verb (2.10 and 2.11) or to verbal compounds whose meaning is somewhat different from the meaning of each verb (2.9). Any other sequence of verbs, especially those involving functional specialization and grammaticalization or which belong to different underlying clauses will be referred to as verb strings (see 4). This will also involve assessing the type of syntactic or semantic relation between verbs in serial constructions, and more broadly, an analysis of dependency in a typological perspective of clause-linkage (see 5 and 6). 


\subsection{Criteria of serial verb constructions in Nêlêmwa}

Serial verbs are generally defined by a set of criteria which also apply to Nêlêmwa: they are verbs or VPs constituting one single predication/clause, one single prosodic entity, sharing syntactic arguments (with a single set of pronominal affixes or nominal arguments), sharing tense, aspect, mood, illocutionary force, polarity and referring to aspects of a single event. Specific to Nêlêmwa is the requirement that the verbs be contiguous, only directionals may intervene between $\mathrm{V}_{1}$ and $\mathrm{V}_{2}$. Each verb should be a full lexical predicate with no loss of semantic, morphosyntactic properties or phonological form. Anything that does not meet these criteria will not be considered as a serial or complex predicate, but as a mere verb string. Thus, in (1), only $\hat{a}$ and kuut are serialized, while the adverb mwadu between kuut and axi is evidence that axi belongs to another clause with an ellipted subject index and does not constitute a serial construction:

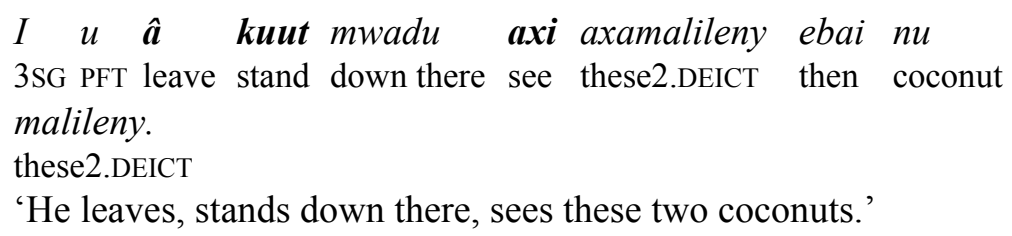

'He leaves, stands down there, sees these two coconuts.'

2.2. The criterion of lexical autonomy: the case of transitivized adjuncts

The requirement of lexical autonomy excludes a number of deverbal adjuncts from serial verb constructions. They cannot be used as autonomous verbs, even though they have preserved some morphosyntactic features from their former verbal category such as their transitive concord ${ }^{3}$ with a transitive $\mathrm{V}_{1}$ in complex predicates (cf. (2)), in contrast with true adverbial adjuncts (hulima 'hastily, disorderly', maya 'slowly, correctly') which never display any transitive concord.

$$
\begin{aligned}
& \text { Hla paare pexagiix-e paara. } \\
& \text { 3PL tell separate-TR story } \\
& \text { 'They tell a story in turns.' }
\end{aligned}
$$

Constructions such as (2) constitute complex predicates, not serial constructions. Among those deverbal adjuncts are: neo(li) 'quietly', hayu(lî) 'haphazardly', pwamapwan(ilî) 'not directly'; gela(lî) 'always, constantly'; hada, hade 'only'; pexagiik ${ }^{4}$ 'each'. 


\subsection{Common patterns and types of verbs prone to serial construction}

Serial constructions are frequent in Nêlêmwa, but they are restricted to some types of verbs and functions. The most common are active and motion verbs as well as stative verbs.

Table 1. Type of verbs.

\begin{tabular}{|c|c|c|c|}
\hline FREQUENCY & frequent $\longleftarrow$ & 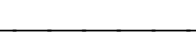 & infrequent \\
\hline TYPE OF VERBS & $\begin{array}{l}\text { motion and } \\
\text { active verbs }\end{array}$ & stative verbs & $\begin{array}{l}\text { Aktionsart, } \\
\text { modal verbs }\end{array}$ \\
\hline \multirow[t]{4}{*}{ SEMANTICS } & $\begin{array}{l}\text { sequential or } \\
\text { simultaneous } \\
\text { actions }\end{array}$ & \multirow[t]{4}{*}{$\begin{array}{l}\text { modification, } \\
\text { manner, } \\
\text { qualification }\end{array}$} & $\begin{array}{l}\text { inchoative, } \\
\text { terminative }\end{array}$ \\
\hline & manner & & \multirow{3}{*}{$\begin{array}{l}\text { (un)able, } \\
\text { know, try }\end{array}$} \\
\hline & purpose, endpoint & & \\
\hline & result (infrequent) & & \\
\hline
\end{tabular}

The most common pattern involves two verbs; sequences of three verbs are infrequent and generally comprise a verb of motion or direction.

- $\mathbf{V}_{\mathbf{1}}$ may host any active or stative predicate and is the open slot,

$-\mathbf{V}_{\mathbf{2}}$ or $\mathbf{V}_{\mathbf{3}}$ as the modifier slot may also host any active or stative predicate, but it is more restricted.

Table 2. Type of verb slots.

\begin{tabular}{|l|l|}
\hline \multicolumn{1}{|c|}{$\mathrm{V}_{1}$} & \multicolumn{1}{c|}{$\mathrm{V}_{2}$} \\
\hline stative $\mathrm{V}$ & $\begin{array}{l}\text { ?? stative } \mathrm{V} \\
\text { intransitive } \mathrm{V} \\
{[* \text { ungramm. transitive } \mathrm{V}]}\end{array}$ \\
\hline active $\mathrm{V}(+/$ - transitive $)$ & $\begin{array}{l}\text { stative } \mathrm{V}(+/ \text { - transitivized }) \\
\text { intransitive or transitive } \mathrm{V}\end{array}$ \\
\hline
\end{tabular}

The only absolute restriction bars the specification of a stative $V_{1}$ by a transitive $\mathrm{V}_{2}$; no example of serial verbs consisting only of stative verbs could be found, all other combinations are possible.

Serial constructions in Nêlêmwa display most of the common rolemarking functions of such constructions (motion, trajectory and direction, manner of action, purpose, modality, Aktionsart), but they exclude causa- 
tive or resultative functions, as well as benefactive or comitative case-role marking.

- $\mathrm{V}_{2}$ may also have argument-expanding function, adding case-roles (such as locative, associative, etc.) which are not part of the verb's semantic structure or which do not have any other morphosyntactic expression;

- $\mathrm{V}_{2}$ may also mark clausal dependency, such as complementation (with the quotative verb khabwe 'say') or subordination (with uya 'arrive' grammaticalized as a conjunction meaning 'until'). This marks the frontier between serial constructions and grammaticalized conjunctive verbs with possible semantic bleaching.

\subsection{Syntactic representation and syntactic functions of SVCs in Nêlêmwa}

In Nêlêmwa, a verb sequence may have various underlying syntactic structures and functions, correlated with various types of predicates. Here are the most common:

(i) sequences of active, co-ranking verbs referring to sequential actions and constituting a multi-headed construction, with verbs sharing the same subject / agent (2.6);

(ii) asymmetric secondary predication in which the verbs share the same subject, but in which an active $V_{2}$ specifies the circumstances of $V_{1}$ (2.7);

(iii) hierarchized, asymmetric head-adjunct constructions, in which the head $V_{1}$ is modified by a fully verbal $V_{2}$ expressing qualification; this follows the general pattern of modification in Nêlêmwa [modified modifier]. $\mathrm{V}_{1}$ and $\mathrm{V}_{2}$ share the same patient, but not the same agent. Transitivity is determined by the head $\mathrm{V}_{1}$ and $\mathrm{V}_{2}$ shows transitive concord with a transitive $\mathrm{V}_{1}(2.8)$;

(iv) complex predicates involving inchoative Aktionsart (2.10) or modality (2.11), with verbs such as shêlâ 'know, be able', mwemwelî 'know', shaya 'move, work, try', kuat 'refuse', thaaxa 'begin'. This other type of asymmetric structure reverses the usual pattern of modification, since $V_{1}$ has scope on $V_{2}$. Yet, none of these verbs may be analysed as auxiliaries, and a different analysis will be proposed.

Table 3. Patterns of specification.

\begin{tabular}{|l|l|}
\hline $\mathrm{V}_{1}<\mathrm{V}_{2}$ & modification, terminative Aktionsart \\
\hline $\mathrm{V}_{1}>\mathrm{V}_{2}$ & modality, inchoative Aktionsart \\
\hline
\end{tabular}


These four types involve different types of verb, in different slots and positions; they have different underlying structures, different patterns of argument sharing, different morphosyntactic characteristics and different properties.

\subsection{Argument sharing and negation}

Argument sharing is the prime distinctive criterion for complex verb constructions. In Nêlêmwa, the nuclear $[\mathbf{s V V}(\mathrm{V}) \mathbf{0}]$ pattern has a unique set of arguments (only directionals may intervene between the verbs) and the negation marker kio has scope over the whole complex (see ex. (3)). Of the four types mentioned above, only the third one, which comprises a modifying stative verb [such as $\mathrm{V}_{3}$ yoo-lî in (3)], displays only patientsharing, as shown by the topicalization of the patient vha nêlemwa in (3b), but no subject-sharing.

(3) a. Kio $i$ tâlâ mwemwelî yoo-lî vhaa Nêlêmwa.

NEG 3SG hear know.TR be good-TR talk Nêlêmwa

'He doesn't understand the Nêlêmwa language very well.'

b. Vhaa Nêlêmwa xe kio i tâlâ mwemwelî yoo-lî.

talk Nêlêmwa TOP NEG 3SG hear know.TR be good-TR

'The Nêlêmwa language, he doesn't understand very well.'

The other types share the subject/agent, but not necessarily the patient. In (4), only $\mathrm{V}_{3}$ 'look for' has a patient, $\mathrm{V}_{1}$ 'go down' and $\mathrm{V}_{2}$ 'fish' being intransitive.
$\mathrm{Na} \mathbf{t u}$
pwe yaagi caaxi caa-hî.
1SG go down fish look for side-dish starch food-POss.1DU.INCL
'I went down (to) fish (and) look for food as a side-dish to our starch-food.'

\subsection{Equally ranked constructions with active verbs}

This is commonly found in narratives. A chain of active verbs, all sharing the same subject, expresses a tight sequence of actions in logical and chronological order and makes up one single event. In this multi-headed construction, with co-ranking verbs, there is an order constraint: a transitive verb (if any) comes last and the verbs do not necessarily share the patient. 
Their order is both pragmatically iconic and consistent with the vo word order of Nêlêmwa and the s(v)VO order of the nuclear serial construction: the intransitive verbs come first and the transitive verbs come last, before the patient. Semantically, they refer to sequential actions, varying with the semantics of the verbs involved in the string.

Mo fhe-dame pae-da bwa on na hmwiny.

2DU take-up here throw-up on sand LOC here

'Bring it up here (and) throw it up onto the shore here.'
Ma $u$ oda uya tu axaleny Boovalan.
1DU.EXCL PFT go up arrive find this man Boovalan
'We went up, arrived, found this Boovalan.'

\author{
Na hla xam oome tuuli hî shaam hleny xe xam \\ but 3PL ASS come here find this plate this.DEICT TOP ASS \\ maat-maat. \\ empty \\ 'And they arrive (and) find the plate which is empty.'
}

\title{
2.7. Complex predicates with specifying active $V_{2 s}$
}

As in 2.6, the verbs share the same subject, but they do not necessarily share the same patient, and if there is a transitive verb in the string, it comes last. But in contrast with 2.6, the $\mathrm{V}_{2}$ specifies the circumstances of the main action expressed by $\mathrm{V}_{1}$ (concomitance, direction, manner of action, result, etc.). Yet, the construction analysed in 2.7 is different from the asymmetric head-modifier complex predicates analysed in 2.8 , which evidence fusion of argument structure.

\subsubsection{Specification of circumstances (concomitance, manner of action, result, purpose, etc.)}

Such complex predicate constructions refer to one single event, comprising a second predicate which expresses concomitance or more generally the circumstances of the main action (manner of action, purpose, result). Their intermediate status between co-ranking and asymmetric structure appears in their English translation, either as coordinate or as participial verbs, but 
apart from semantics, nothing distinguishes them from the co-ranking serial verbs (in 2.6).

(8) Me $i$ u gaa gi kââleng, gi kââleng. CONJ 3SG PFT PROG cry circle cry circle

'And she keeps going around and cries/crying, going around crying.'

(9) Hla thege oga hî pwiak.

3PL run leave this.DEICT net

'They run and leave/leaving the (fishing) net.'

$\mathrm{V}_{2}$ specifying manner of motion

(10) yha cap 'escape swimming' ( $y$ ha 'swim' + cap 'run away')

tha coot 'fish on foot' (tha 'spear fish with assagai' + coot

'cross a ford')

thege pwiidi 'run dragging' (thege 'run' + pwiidi 'drag')

(11) Hla thege oga hî pwiak.

$3 \mathrm{PL}$ run leave this net

'They run leaving this fishing-net.'

$\mathrm{V}_{2}$ specifying manner or result of action:

(12)
oda tâimi 'go up grabbing (a rope)'
khaayi mode 'break (by) tugging' (khaayi 'pull', mode "break')
tîlîxxââ nap 'pretend to be angry' (tîlîxââc 'be/get angry', nap 'lie, deceive')

(13) I mago thu cong.

3SG sleep do be stubborn

'He keeps on sleeping.'

In (14a) noolî specifies the manner of action, but also undergoes some degree of co-lexicalization (since it also means 'ignoring' or 'not paying much attention to them'); whereas (14b) expresses sequential or purposive action and could be rephrased as a dependent clause with $m e$ 'and/to':

(14) a. Hla wâlem noolî.

3PL walk see.TR

'They ${ }_{x}$ pass watching them.'

b. Tu noolî.

go down see.TR

'Go (and/to) see them.' 
The sequence may consist of two (or more) transitive verbs sharing the same patient (15a). It may also be rephrased as a dependent clause with me (15b):

(15) a. Hâ tami kaamwa-le bwat hleny?

1PL.INCLopen do how?-TR box this.DEICT

'How do we open that box?'

b. Co kaamwa-le me yo payailî mashin hleny?

2SG do how?-TR CONJ 2SG set in movement-TR machine this.DEICT 'How do you do to start this machine?"

Compare the complex verb construction with harat, harar-ili 'hurry, do in a hurry' (16b) and the dependent clause with me (16c):

(16) a. axo yo harar-ilî!

PROH 2SG hurry-TR

'Don't speed it!'

b. I diya harar-ili shaya eli.

3SG do hurry-TR work this.ANAPH

'He did the work in a hurry.'

c. Na harat me na toven.

1SG hurry COMP 1SG finish

'I'm hurrying to finish.'

\subsubsection{Specification of direction, trajectory and motion, position}

This use of the complex verb construction is restricted to cases when no other morphological or lexical marker is available, whether directionals, modifiers (bwabwali 'sideways') or prepositional nouns (nanamwa-t 'middle').

$\mathrm{V}_{2}$ specifies trajectory or direction:

$$
\begin{array}{ll}
\text { o biiyet } & \text { 'go around' (o 'go', biiyet 'go around') } \\
o \text {-xâalleng } & \text { 'go around' (kââleng 'circle, surround') } \\
\text { fuk-xââleng } & \text { 'fly around' (fuk 'fly') }
\end{array}
$$

(18) Hla mu kââleng i aayo.

3 SG stay surround CONN chief

'They stay around the chief.' 
(19) I fuk ulep daxi ni fwaa-mwa.

3SG fly cross threshold up away in hole-house

'It flies into the house.' (lit. through the door)

$\mathrm{V}_{2}$ specifies the endpoint of the motion or trajectory expressed by $\mathrm{V}_{1}$ :

(20) I caabwat-da kuut.

3SG get-up stand

'He gets up to his feet.'

$\mathrm{V}_{2}$ specifies position:

(21)

Hli $u$ not kuut mwadu.

3DU PFT look stand down there

'They watch standing down there.'

2.8. Asymmetric, head-adjunct constructions: manner, qualification

As a general rule, the verbal adjunct, whichever its category (active or stative verb), comes last and expresses a wide range of meanings. The $\mathrm{V}_{1}$ and $\mathrm{V}_{2}$ constitute one complex predicate with fused argument structure inherited from the $\mathrm{V}_{1}$ 's argument structure. Consider (22a, b):

(22) a. I diya mwang.

3SG do be bad

'He acted badly.'

b. I hnawe mwang-ilit.

3SG drop be bad-TR

'He dropped it akwardly.'

In (22a, b), the $\mathrm{V}_{1}$ and the $\mathrm{V}_{2}$ evidence argument fusion not argument sharing: they have different underlying subjects and in (22b), the stative verb mwang inherits the patient of $\mathrm{V}_{1}$; this is signalled by its transitive concord with $\mathrm{V}_{1}$.

Argument fusion and head-driven transitive concord on $\mathrm{V}_{2}$ (marked by one of various transitive suffixes $\left.-e,-l e,-(i) l l^{5}\right)$ signal asymmetric constructions and complex predicates rather than serial verbs (see Aikhenvald 1999: 482; Foley \& Van Valin, 1984: 208-210). The tight integration of the constituents of such complex predicates stands in contrast with the looser syntactic dependency of multi-headed serial constructions in which no such concord ever occurs (see 2.6). 
Among the most common stative verbs to appear as $V_{2}$ in such constructions are:

sho 'be good', mwang 'be bad', khare 'be different', fwaat 'be clear', bööm 'be soft, gentle', hââhuuk 'be recent, new', shuva? 'be how?'; shumwêlî 'be thus'.

Compare the following, in which the $\mathrm{b}$. examples display transitive concord:

(23) a. Mee-yo ${ }^{6}$ (mee 'be ripe', sho 'be good') 'It's fully ripe.'

b. Co gaa tili-yoo-lî na le kak.

2SG PROG sweep-be good-TR LOC LOC.ANAPH forest

'Go on cutting the undergrowth.'

(24) a. Hla pe-xare.

3PL REC-be different

'They are different from one another.'

b. Hla o pe-xare.

3PL go REC-be different

'They go their own way.'

c. Na pe-xare-lî́

put REC-be different-TR

'Put them apart!'

In (24c), the reciprocal predicate pe-xare 'be different from each other', derived from the verb khare 'be different', shows transitive concord with a transitive $\mathrm{V}_{1}$. Here are some additional examples of such sequences:

a ni-xare 'go away separately' ( $\hat{a}$ 'leave, go'); fhe-xare 'take somewhere else' (fhe 'take, carry'); mu-xare 'live separately' (mu 'stay'); na-xare 'put separately' ( $n a$ 'put'); ni-xare 'send s.o. elsewhere' ( $n i$ 'send'); $o$ xare 'go away separately'.

The Aktionsart verb hâahuuk 'be recent, new' may be transitivized as $\mathrm{V}_{2}$ :

(25) a. Hââhuuk fwâhuux-eli.

be recent story-that.ANAPH

'This story is a recent one.'

b. Hla diya hââhuux-e mwa eli.

3PL do be recent-TR house that.ANAPH

'They built this house recently.'

So can the similative verb shumweli 'be thus': 


\section{Ehleena na khabwe shumwelî-le. these 1SG say in this way.TR} 'These are (the words) I thus said.'

2.9. Complex verbs, specialization, co-lexicalization or compounding?

The specification of a $V_{1}$ by a verbal adjunct $V_{2}$ (as in 2.8) does not imply any categorial change, just a functional change induced by its syntactic position, in keeping with the general pattern of determination [determiner determined]. Some of these constructions may gradually gain some degree of semantic specialization or may even become grammaticalized, entailing some loss of autonomy, a reduced semantic range or some morphosyntactic modification. Here are a few cases which range from specialization to co-lexicalization, with some fuzzy frontiers between them.

\subsubsection{Functional and semantic specialization}

Some verbs of motion or direction ( $\hat{a}$ 'go, leave', wâlem 'walk' ${ }^{8}$ ) may specialize as modifiers expressing manner of action in $\mathrm{V}_{2}$ position, with a slightly different meaning, like pavange wâlem 'get ready quickly' (27). These verbs are not grammaticalized, they only specialize as modifiers in $\mathrm{V}_{2}$ position and retain their full lexical meaning in other collocations and sometimes even in $\mathrm{V}_{2}$ position ( $\hat{a}$ wâlem 'go walking').

$$
\begin{array}{ll}
\text { wâlem tabö } & \text { 'walk (and) go downhill' } \\
\text { pavange wâlem } & \text { 'get ready quickly' } \\
\hat{\boldsymbol{a}} \text { wâlem } & \text { 'go walking' } \\
\text { wâlem } \hat{\boldsymbol{a}} & \text { 'go from place to place' } \\
\hat{\boldsymbol{a}} m u & \text { 'go settle' } \\
\text { mu } \hat{\boldsymbol{a}} \text { ('stay'+'leave') } & \text { 'live from place to place' } \\
\hat{\boldsymbol{a}} \text { pexare (pexare 'be different') } & \text { 'go separately' } \\
\text { pexare } \hat{\boldsymbol{a}} & \text { 'be different from place to place' }
\end{array}
$$

In $\mathrm{V}_{2}$ position, $\hat{a}$ 'leave, go' may specialize as an adverbial adjunct with dispersive meaning 'from place to place' or remain a full motion verb as in (28a); example (28b) exemplifies both positions and functions (motion verb and modifier). Function and meaning are thus context-dependent and vary with the degree of idiomatic conventionalization or lexification of a specific collocation: 
(28) a. Êna xe co $\boldsymbol{k} \boldsymbol{u} \quad \hat{\boldsymbol{a}}$ me yo $\hat{\boldsymbol{a}}$ oda

now TOP 2SG stand leave CONJ 2SG leave go up

ni hoona mwa.

in this.DEICT house

'Now, get up, go and get into that house.'

b. Hla $\hat{\boldsymbol{a}} \boldsymbol{m \boldsymbol { u }} \hat{\boldsymbol{a}}$.

3PL leave stay leave

'They left to live from place to place.'

In some cases, a verb has more abstract meaning when used as a $V_{2}$ in a serial construction. This is the case of bwage 'turn around, go back' which has abstract, reversive meaning as $\mathrm{V}_{2}$ :

(29) no bwagi 'look back, look behind'

fhe bwage 'give back' (fhe 'take, carry').

(30) Wa axe dau hleny, hla wâlem bwage agu na bwaa-t. 2PL see island this.DEICT 3PL walk return people LOC top 'You see this island, people stopped there on their way back.'

(from a trip to the neighbouring islands).

Similarly, after a $\mathrm{V}_{1}$ of perception, $u y a$ 'reach, arrive' specializes as an endpoint marker with the meaning of 'up/down to' showing incipient grammaticalization, but less so after a $\mathrm{V}_{1}$ of motion:

(31) I $\hat{\boldsymbol{a}}$ uya awôlô Soop.

3SG leave arrive home Soop

'He leaves, arrives at Soop's house (or) he goes up to Soop's house.'

(32) Kââlek o $i$ no-du uya fwâ-jahoot be impossible VIRT $3 \mathrm{SG}$ see-down reach mouth-river

'It is impossible for him to see down to the mouth of the river.'

\subsubsection{Incipient grammaticalization and categorial change}

The verb khoon 'carry sth on one's shoulders, bear', whose transitive form is $k h \hat{o} l \hat{\imath}$, may appear as $\mathrm{V}_{2}$ in a complex verb construction, under its lenited form $x \hat{o} \hat{o} l \hat{\imath}$, with the more abstract reading of 'grudgingly'.

(33) I diya xôoli.

3SG do bear.TR

'He did it grudgingly.' 
The two verbs v.i. fuung, v.t. funge 'gather, heap up', and v.i. fiing, v.t. viing $(e)^{9}$ 'join, put end to end' have similar constructions. As $\mathrm{V}_{2}$, fuung has its lenited form wuung, wuuge ${ }^{10}$ meaning 'together'.

(34)a. Hla fuuge nu.

3PL gather coconut

'They're heaping up coconuts.'

Compare the scope of wuuge, on the patient in (34b) and on the agent in (34c) which suggests that it is being grammaticalized as an adjunct, since it can have scope over the subject or the patient according to context.

b. Hla hnaxi wuuge shâlaga malaaleny.

3PL tie together-TR crab these.DEICT

'They tied these crabs together.'

c. Hla diya wunge fagau mwa eli.

3PL do together-TR body house this.ANAPH

'They built the wall of the house together.'

Examples $(34 a, b)$ are reminiscent of the scope of the secondary predication, as in she ate her meat raw and she left the party angry, which are close equivalents to core serial construction in other languages, as pointed out by Larson (1991: 201). Thus, the syntactic structure alone is underspecified and it is contextual semantics that orients the secondary predication towards either the agent or the patient.

There are a few cases when an intransitive verb, such as niiva 'err, be wrong, be lost, make a mistake', which normally requires a causative or factitive derivation to be transitivized (fa-niiva-(v)i(lî) 'deceive, lose s.o.'), may show transitive concord under a slightly different form (niivalî) which only appears in complex verb constructions (35c). It starts behaving like stative qualifying verbs (mwang, sho, etc.), thus signalling a change of category in one of its usages. Its meaning varies with the category of $\mathrm{V}_{1}$, but generally expresses absence of control and detrimental meaning. With verbs of motion, niiva(lî) means 'by mistake, aimlessly', with other verbs, it means 'without any reason, wrongly'.

(35) a. I niiva.

3SG make a mistake

'He made a mistake.'

b. Hla peâi niiva.

'They fight without any reason.' 


\section{c. I diya niiva-lî shaya eli.}

3SG do make a mistake-TR work that.ANAPH

'He did this work wrong.'

\subsubsection{Incipient lexification and morphological change}

In the case of not 'see', the loss of the final consonant signals incipient co-lexicalization, as opposed to the serial construction which retains its full form (see ex. (21)). Here are a few examples:

no-xiluuk 'look from under' (kiluuk 'bend'); no oxuri 'follow with one's eyes' (oxuri 'follow, go along'); no mwimwi 'recognize on seeing' (mwimwi 'know'); no huu 'follow with one's eyes, look for' (huu(ri) 'follow'); no-yêlâ 'recognize' (shêlâ 'know').

But most often, there is no morphological change to distinguish co-lexicalized verbs from serial verbs and only semantic notions hold, such as the fact that co-lexicalization creates more complex verbal concepts to make up for a lexical or morphological gap. Nor should intervocalic sandhi ${ }^{11}$ be considered as a sure sign of co-lexicalization, but it does signal asymmetric serial constructions with modifying function.

po-radi 'make noise when tearing' (pot 'make noise', thadi 'tear'); tili-xibwaat 'scatter' (tili 'sweep', kibwaat 'throw away'); khaayi mode 'break (by) tugging' (khaayi 'pull, tug, hoist', mode 'break'); o-rurua 'pass by hiding' (o 'go', thurua 'hide'); shaya thurue / shaya-rurue ${ }^{12}$ 'do sthg on the sly' (shaya 'work' + thurue 'hide, bury sthg'); shaya $k u-(x)$ âyoot or shaya kwâyoot ${ }^{13}$ 'do sthg on the sly' (kwâyoot 'hide'); tîlîxââc nap 'pretend to be angry' (tîlîxââc 'get, be angry', nap 'lie, deceive'); yaat abwe 'thatch with the roots of the straw downwards' (yaat 'thatch' + abwe 'deviate, send back'); kole pwa 'decant' (kole 'pour', pwa 'fold, bend, break, snap'); pwa nibi 'fold again' (nibi 'fold'); pwa khabwe 'answer back' (khabwe 'say').

That such specifications should be expressed by verbs rather than by prepositions, directionals, participial verb forms, nominal forms, etc., is a language-specific phenomenon. Nêlêmwa and English have similar strategies with motion verbs, though they use different morphemes, whereas French uses participial or nominal forms. Compare: fuk ulep 'fly out'/ 'sortir en volant'. The degree of predictability and conventionalization of such expressions may in turn lead to gradual semantic specialization and true compounding. 


\subsection{Aktionsart verbs in serial constructions}

Aspect is mostly marked by preverbal morphemes in Nêlêmwa, except for inchoative and terminative aspects which are expressed by Aktionsart verbs. Among them, only thaaxa 'begin, start' and kûûlî 'finish, complete' admit serial constructions, toven 'finish, stop' requires a dependency marker. This is evidence that their construction is constrained by the syntactic and argument structure of the verb and does not just correlate with semantics. Similarly, the position of thaaxa and kûûl î is iconic (with inchoative in $\mathrm{V}_{1}$ position and terminative in $\mathrm{V}_{2}$ position), unlike that of toven, which always appears as $\mathrm{V}_{1}$ with a complementizer.

Table 4. Construction of Aktionsart verbs

\begin{tabular}{|l|c|l|l|}
\cline { 3 - 4 } \multicolumn{2}{c|}{} & \multicolumn{2}{c|}{ order } \\
\hline Inchoative & SVC & thaaxa $+\mathrm{V}_{2}$ & \\
\hline Terminative & SVC & & $\mathrm{V}_{1}+$ kûûli \\
\hline Terminative & NO SVC & toven $\mathrm{o}+\mathrm{V}$ & $\mathrm{V}+$ roven $^{14}$ \\
\hline
\end{tabular}

(36) Wa thaaxa shaya!

2PL start work

'Start working!'

I shaya xûûlı̂' ${ }^{15}$.

3SG work finish

'He worked at it till completed.'

Could the verb string in (36) be interpreted as a complementizing construction of $\mathrm{V}_{1}$ and could (37) be a modifying serial construction? In (37), $\mathrm{V}_{2}$ kûûlî, with its weakened form xûûli, might undergo some degree of specialization as an aspectual modifier; as yet, it is a secondary predicate that specifies the end of the process marked by $\mathrm{V}_{1}$. In the case of thaaxa, the nuclear serial construction is restricted to intransitive $V_{2 s}$, while a transitive $\mathrm{V}_{2}$ triggers an obligatory two-clause construction, marked by the general dependency marker (coordinator or subordinator) me. Thus, (38) with obligatory coreferential subject pronouns for the two verbs can either be interpreted as a coordinate construction (in a.) or as a complement clause (in b.). 
(38)a. [I $\mathbf{I}_{\mathbf{x}}$ thaaxa] $\boldsymbol{m e}$ [i $\mathbf{i}_{\mathbf{x}}$ khuxi a âlô hleny kuvic hleny].

b. [I $\boldsymbol{I}_{\mathbf{x}}$ thaaxa [me $\boldsymbol{i}_{\mathbf{x}}$ khuxi a âlô hleny kuvic hleny]]. 3SG start COMP 3SG eat.TR AGT child this.DEICT yam this.DEICT

'The child starts eating the yam.'

The two constructions of thaaxa according to the valency of $\mathrm{V}_{2}$ could be unified as being two expressions of dependency, either as a tight complex predicate referring to one event (36), or as a dependent clause (38a, b).

Example (39a) shows that a verb sequence may contain various hierarchical levels: a loose co-ranking relation between the motion $\mathrm{V}_{1}$ tuume and the other verbs, since it can be autonomized as two sentences referring to two events (as in 39b), in contrast with the tight syntactic and semantic dependency between $V_{2}$ and $V_{3}$, thaaxa specifying the initial phase of haga.

\section{(39)a. Hli tuume thaaxa haga \\ 3DU go down start fish \\ 'They go down (and) start fishing.'}

b. Hli tuume, hli thaaxa haga 'They go down, they start fishing.'

\subsection{The case of modal $\mathrm{V}_{1}$}

A few full verbs with modal semantics appear as $\mathrm{V}_{1}$ with scope on $\mathrm{V}_{2}$ : kuat 'refuse', shêlâ 'know, can, be able', mwemweli 'know', shaya 'move, work, try, attempt'. These are distinct from modal modifiers which also appear in preverbal slot, but which are not autonomous verbs and might be former verbs grammaticalized as modal predicates: koni 'unable, impossible', jara 'desire, feel like'.

In (40a), $\mathrm{V}_{1}$ shêlâ has scope over $\mathrm{V}_{2}$ and $\mathrm{V}_{3}$, and all the verbs share the same subject. Since such constructions reverse the usual order of modification, what kind of underlying syntactic structure can account for this?

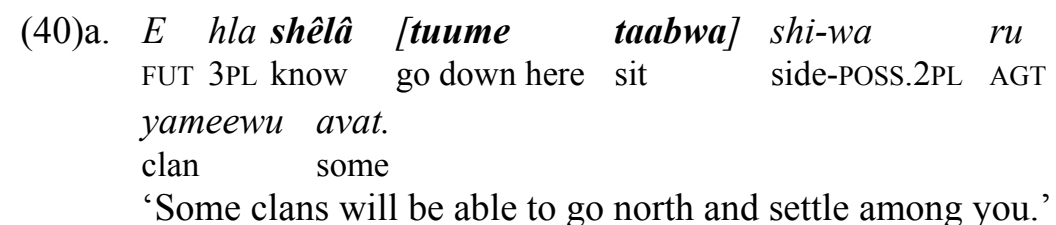

There seems to be a conflict between the syntactic and the semantic structure of such sequences. $\mathrm{V}_{1}$ shêla behaves as the syntactic head of a 
complementizing structure, with $\mathrm{V}_{2}$ and $\mathrm{V}_{3}$ as its syntactic complements; yet, the semantic node is expressed by $\mathrm{V}_{2}$ and $\mathrm{V}_{3}$, and shêla is an optional modal specifier (compare 40a, b). There are different hierarchies as well, $\mathrm{V}_{2}$ and $\mathrm{V}_{3}$ are co-ranking but are under the scope of $\mathrm{V}_{1}$ :
b. E hla [tuume taabwa] shi-wa ru yameewu avat. FUT 3PL go down here sit side-POSs.2PL AGT clan some 'Some clans will go north (and) settle among you.'

The verbs share the same subject pronoun and the scope of negation bears on the whole sequence:
(41)a. Kio na mwemwelî bwagi-na o khabwe kiya Kaavo NEG 1SG know return-1SG VIRT say there is no Kaavo
mudi-ny. company-Poss.1sG 'I can't go back without Kaavo in my company.'

b. Kio na bwagi-na o khabwe kiya Kaavo mudi-ny. 'I won't go back without Kaavo in my company.'

Nor are these verbs modal auxiliaries, they remain full lexical verbs whose modifying function as modal predicates is context-dependent or position-dependent. In (42a), shaya 'move, work' is the head specified by $\mathrm{V}_{2}$ harat 'hurry', whereas in (42b), shaya is the specifier meaning 'try':

(42)a. I shaya harat.

3SG move be in a hurry

'He works in a hurry.'
b. I shaya $\hat{a}$-yayap ${ }^{16}$.
3SG move go-RED.escape
'He's trying to escape.'

Thus, the polysemic verb shaya specializes as a modal predicate in some collocations, but shows, as yet, no sign of grammaticalization as a modal auxiliary. Only once they have reached an advanced degree of grammaticalization and divergence from the original lexical root do they become homophonic elements with possibly fairly different meaning.

The complex verb construction is thus one of the two possible complementation strategies for a few verbs with modal semantics. One of the verbs is then construed as the argument of another verbal head, according to such factors as control of coreference (43) or transitivity of $V_{2}$. Thus kuat 'refuse' admits a tight complex verb construction (43a) when the verbs share the same subject/agent, but a "deranked" complementation marked by 
the irrealis marker $o$ otherwise. In (43a), the verbs are not co-ranking, since $\mathrm{V}_{1}$ modifies $\mathrm{V}_{2}$, but at least, there is no morphological imbalance as in $(43 c)$.

(43)a. Hla kuat axe fwamwa pwagiik o $i$ oda.

1SG refuse see country CLASS-one VIRT 3SG progress

'They refuse to see a place that's making progress.'

\section{b. I $I_{\mathbf{x}}$ kuat yagei-e $e_{\mathbf{y}} a \quad P w \hat{a}-K e b \ddot{o}_{\mathbf{x}}$.}

3SG refuse help-3SG AGT Pwâ-Kebö

'Pwâ-Kebö refuses to help him.'

c. $I_{\mathbf{x}}$ kuat o $i_{\mathbf{y}}$ yagei- $e_{\mathbf{x}}$ a Pwâ-Kebö ${ }_{\mathbf{y}}$. 3SG refuse VIRT 3SG help-3SG AGT Pwâ-Kebö

'He refuses that Pwâ-Kebö (should) help him.'

\section{Syntactic and semantic constraints to serial verb construction}

Complex verb constructions (CVCs) often play the role of a morphosyntactic gap-filler, expressing directional ${ }^{17}$, aspectual or case-marking functions by lexical rather than morphological means. In Nêlêmwa, syntactic constraints on the use of CVCs are of two types: (i) to license an argument that is not part of a verb's argument structure; (ii) to license an additional argument to an otherwise intransitive verb.

\subsection{Verbal semantic structure}

The role of the CVC is to license an argument whose semantic features are not compatible with the main verb's. Thus, in (44), uuri 'carve, sculpt, scrape' requires an inanimate patient and the complex verb licenses an animate patient (uuri uyamwilî: lit. carve imitate):

(44)a. I uyamwi kââma-n.

3SG imitate father-POSS.3SG

'He imitates his father.'

b. I uuri uyamwilî fagau-t agu.

3SG carve imitate body person

'He's sculpting a person's body.'

The same goes with tii 'write, draw': tii uyamwili 'draw (a person)'. 
3.2. Valence increase and case-marking function: locative complements

It is a common cross-linguistic fact in Austronesian and African languages that serial constructions may have valency-increasing function and integrate more participants than the basic arguments which are part of a verb's argument and syntactic structure. Thus, Austronesian languages, which generally do not allow ditransitive verbs or constructions ${ }^{18}$, make use of serial constructions to integrate and case-mark such participants as beneficiary, comitative, instrumental and even directional or locative complements.

In Nêlêmwa, participants other than the basic arguments are usually marked as prepositional phrases and infrequently by complex verb constructions. Yet there are a few such cases with the verbs oxo (+animate) or oxuri (+inanimate) 'follow' $(45,46)$, which are both direction markers and argument-expanding devices licensing a patient (thaamwa, (45)) or a locative complement (hî mat, (46)) to an otherwise intransitive $\mathrm{V}_{1}$ such as thege 'run', $o$ 'go', wâlem 'walk' or teewot 'sail before the wind'. Again, they serve as lexical and morphological gap-fillers, since there is no other preposition or directional marker to express such notions as 'after' or 'along'.

I thege oxo thaamwa.

3SG run follow woman

'He runs after the woman.'

(46) I u haga o oxuri-da hî mat, [...]

3SG PFT fish go follow-up this low tide

oda-xi uya Fhalap.

go up away reach Fhalap

'She goes fishing following the (low) tide, goes up away, reaches

Fhalap.'

(47) I $u$ wâlem oxuri hnawa horaamwaleny Kaavo.

3SG PFT walk follow trace this woman Kaavo

'He walks following Kaavo's footprints.'

(48) I $u$ oot oxuri ve on.

3SG PFT sing follow DIR sand

'He sings along the beach.' (* $i$ oot ve on is ungrammatical) 


\section{I $u$ teewot oxuri kuru.}

3SG PFT sail before wind follow wind

'He sails following the wind / before the wind.'

In some of its usages, oxuri 'follow' may (though more infrequently) also specialize as a specifier meaning 'according to' and express quantification and degree, as in (50), where $\mathrm{V}_{2}$ jaxe 'measure' normally requires a concrete patient. $\mathrm{V}_{3}$ oxuri licenses the quantification of an abstract notion (money) and thus bypasses the constraint on the semantic frame of jaxe:

$$
\begin{aligned}
& \mathrm{Na} \text { iyuli jaxe oxuri jaxa mwani } i \text { na. } \\
& \text { 1SG buy.TR measure.TR follow.TR measure money CONN 1SG } \\
& \text { 'I bought enough of it according to what money I had.' (lit. } \\
& \text { according to the amount of my money." }
\end{aligned}
$$

The verb string in (50) is not a serial construction since the verbs have different patients: the patient of $\mathrm{V}_{1}$ is the thing bought, whereas the patient of $\mathrm{V}_{2}$ is the amount of money required for that; as for $\mathrm{V}_{3}$, it evidences functional specialization as a valence-expanding device. The specialized use of a verb 'follow' as a case-marking or valency-expanding device is also attested in Ajië (New Caledonia), where two verbs (vèri 'follow' and xara 'be at') have grammaticalized as prepositional associative markers. See also example (51) in Mwotlap (François, this vol.) and Paamese (Crowley 1987: 67).

\section{Complex verb constructions and clause dependency}

This section analyses complex verbs in the overall system of VP or clause linkage (coordination, complementation or subordination) with a typological perspective. It will focus on the syntactic function of two verbs ${ }^{19}$ used as clause-dependency markers in complex verb constructions in Nêlêmwa: uya 'reach, arrive', which is grammaticalized as a time boundary conjunctive marker with the reading 'until', and the quotative verb khabwe 'say' which is the complementizer of discourse, cognition and more rarely perception verbs:

tâlâ khabwe 'hear, understand that', shêla khabwe 'know that', nanami khabwe 'think, believe that', hâuk khabwe 'not know that', hangi khabwe 'suppose that'. 
(51) Na u hangi khabwe kebuk.

1SG PFT suppose say be true

'I supposed it was true.'

The following tries to assess the frontier between the lexical use of khabwe in a serial verb construction and its grammaticalization as a complementizer. But this is a context-dependent continuum, with synchronically coexistent functional layers. In (52), all verbs share the same subject and khabwe retains its full lexical meaning 'say', thus counting as a case of serialization.

(52) Co mwa â shinook khabwe je a da

2SG ASS leave glance say be.LOC POTENT what?

ni hoona mwa.

in this.DEICT house

'Go, take a look (and) tell us what is in that house.'

By contrast, in (53), the verbs do not share the same subject, $\mathrm{V}_{1}$ tâla is a verb of perception and khabwe undergoes some semantic bleaching as the complementizer of tâlâ:

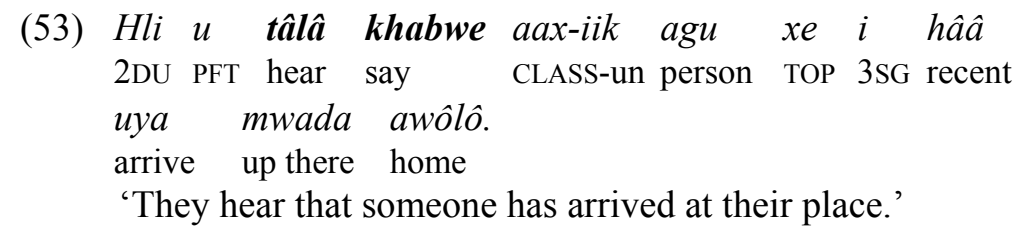

Similarly, in (54), the verb sequence is hierarchized, $\mathrm{V}_{2}$ thabwi is the modifier of $\mathrm{V}_{1}$ and constitutes a complex predicate, while khabwe is a partially grammaticalized complementizer, since most of its meaning is preserved ('able to say'):

(54) Kia ho $i$ mwemweli thabwi khabwe je $p a \ldots$ there is not this $3 \mathrm{SG}$ know take care say be(LOC) where?

hooli foliix-eli.

that.ANAPH thing-ANAPH

'Nobody really knows where that object is.' (lit. nobody really can say where...)

By the criteria used so far, the four-verb string in (55) is not a serial construction, for it contains various types of hierarchized constituents, some of them with functional specialization: 
I no than khabwe kââlek o $\quad i \quad$ no-du

3SG see close say be impossible VIRT 3SG see-down

uya fwâ-jahoot.

reachmouth-river

'He can't see anything, for it is impossible for him to see down to

the mouth of the river.'

(i) The verbs do not share the same subject; (ii) $V_{2}$ than specifies $V_{1}$ and constitutes a co-lexicalized sequence or a compound verb ${ }^{20}$ meaning 'have one's view blocked, see nothing'; (iii) $\mathrm{V}_{3}$ khabwe 'say' is grammaticalized into an explicative marker meaning 'that is to say ${ }^{21}$; (iv) finally, $\mathrm{V}_{4}$ kââlek 'be impossible' has scope on the following clause and the verb string belongs to different underlying clauses. This is evidence that a surface collocation is misleading and requires closer analysis. It also reveals the limits of prosody as a criterion, since no perceptible pause can help dissociate the verbs in (55).

\section{Paratactic, serial or dependent constructions}

Serial constructions may be syntactically constrained, but there are some discourse options between various types of dependencies: paratactic or serial or dependent constructions with dependency morphemes.

\subsection{Serial verbs vs dependent construction: a discourse choice}

Such verb strings are sometimes analysed as resulting from ellipted dependency markers. In Nêlêmwa, this could only hold true with active verbs, as in (56), but its explicative value is not very far-reaching, since it does not explain why such condensed structures exist at all in a particular system and not in all languages, nor does it explain the semantic, discourse or conceptual differences between a serial construction and a dependent clause.

\subsubsection{Serial vs coordinated verbs}

Corpus analysis of narratives shows that serial verbs or VPs and clauses conjoined with me and $x a$ 'and' are more common than paratactic constructions. Serialized active verbs refer to one single event comprising 
several immediately sequential or simultaneous actions (56a); whereas dependent multi-clause constructions refer to two different events (56b) or stress argumentative or logical links between them.

$\begin{array}{lllllll}\text { (56) a. } & \text { Na yo thege } & \text { ulep } & \text { me } & \text { yo } & \hat{a} & b w a \\ \text { CONTR } & \text { 2SG run } & \text { cross threshold } & \text { CONJ } & \text { 2SG go on } \\ \text { maa-on bai } & \text { mwexi. } & & & \\ \text { point-sand that.ANAPH } & \text { there }\end{array}$

'Run out and go to the tip of sand over there.'
b. $\mathrm{Na} \quad \mathrm{i}$ xau
thegela ${ }^{22}$ me $i$ ulep.
CONTR 3SG ASS.PONCT run
CONJ 3SG cross threshold
'And she runs and goes out.'

The same goes for $(57 \mathrm{a}, \mathrm{b})$, the coordination marker $x a$ 'and also, too' refers to two distinct events, although $x a$ signals a more immediate sequence than $m e$ :

(57) a. Hla oda kuut ni hooli yang.

3PL go up stand in that.ANAPH festival

'They go (south) to take part in this festival.'

b. I tu axaleny dagiiny $\boldsymbol{x a}$ kunt ni hooli civa. 3PL go down this man messenger also stand in that.ANAPH dance 'The messager goes down and takes part in the dance.'

(58) a. I u no-da axe mweyaayec xe pwa-giik. 3SG PFT look-up see house TOP CLASS-one 'He looks up (and) sees a house.'

b. $I \quad u$ no-du me $i \quad u$ axe. 3SG PFT look-down CONJ 3SG PFT see 'She looks down and sees it.'

\subsubsection{Serial vs dependent purposive clauses}

The choice of a serial construction with a $\mathrm{V}_{1}$ of motion and an active $\mathrm{V}_{2}$ (59), rather than a dependent clause, is a discourse strategy meant to increase rhythm and compress information. Most of the time, the serial construction can be rephrased as a dependent clause with $m e$, with the same ambiguity between a coordinate reading 'and' and a subordinate purposive reading 'in order to'. But the complex clauses stress argumentative or logical links. 
(59) a. Na i khabwe: "tu thoogi-e dame awôlo". COORD 3SG say go down call-3SG uphere home 'And he says: "go down (and/to) invite her up here at home".'

b. Na hla aa tu me hla thoogi-e da awôlô.

COORD 3PL ITER go down CONJ 3PL call-3SG up home

'And they go down again and / to invite her up there to their home.'

(60) a. Wa oome thu da?

2PL come do what?

'What did you come here for?'

b. Wa oome me wa thu da?

2PL come CONJ 2PL do what?

'What did you come here to do?'

c. Wa oome me pwaxa thu da?

2PL come CONJ necessity do what?

'What's the purpose of your visit here?'

It is a cross-linguistic tendency for serial verbs comprising a motion verb and an active verb to have this double (coordinate or purposive) reading. Whereas complex verbs comprising a stative $V_{2}$ (as in 61a) impose an asymmetric, modifying reading, and exclude the purposive reading; nor can they be interpreted as resulting from deleted dependency markers. Compare:

(61) a. I diya mwang-ilî mwa.

3SG do be bad-TR house

'He built the house in the wrong way.'

b. I diya me mwang mwa.

3SG do CONJ be bad house

'He made it so as to spoil the house.' (lit. he did things in such a way that the house was spoiled)

Example (62) also questions the notion that serial constructions result from ellipted dependency markers and gapping, for the ellipted coreferential pronouns in the second part of (62) do not result in serial constructions, but in paratactic clauses: 
(62) $\underline{\text { Oda }}$ mwa ye, gi ye mwaida awôlô, go up ASS 3sG.Fr be.LOC 3sG.FR up there home Ofhe-me hooli cet, take-here that.ANAPH pot

'She goes up, she's up there at home, brings that pot,

$\begin{array}{clll}\boldsymbol{O} \underline{\text { na-daxi }} \quad \text { bwa } & \text { to, } & \boldsymbol{O} \frac{\text { kole-duxi }}{\text { put-up away }} \text { on stones } & \text { wi. } \\ \text { pour-down away } & \text { water } \\ \text { puts it down on to the hot stones, pours water into it.' }\end{array}$

Compare (62) with the coordinated clauses (63), which slow down the narrative rhythm and convey a feeling of pain and difficulty:

$$
\begin{array}{lllll}
\boldsymbol{m} \boldsymbol{e} \quad \boldsymbol{i} \text { oda-me } \boldsymbol{m} \boldsymbol{e} \quad \boldsymbol{i} \text { pe-thalic } & \boldsymbol{m} \boldsymbol{e} \\
\text { CONJ 3SG come up here CONJ } & \text { 3SG INTENS-stumble } & \text { CONJ } \\
\boldsymbol{i} \text { pe-kâlap mwa bwabuk. } & & \\
\text { 3SG INTENS-lie ASS below } \\
\text { 'And she comes up here and she keeps stumbling and she keeps } \\
\text { falling to the ground.' }
\end{array}
$$

And similarly in $(64 \mathrm{a}, \mathrm{b})$ :

(64)a. Oôxi Pwâ-Kebö Ø khure shi Pwâ-Hivic. approach Pwâ-Kebö touch hand Pwâ-Hivic 'Pwâ-Kebö approaches, takes Pwâ-Hivic's hand.'

b. Pwâ ôoxi me yo shaavic mwa. a.little approach CONJ 2SG warm ASS

'Come closer and/to get warm by the fire.'

Serial verbs express immediately sequential or simultaneous actions, whereas the dependency marker refers to a distinct event:

(65) Yo xau coot-ve tâimi shi horaamweeli Kaavo 2SG ASS.PONCT jump-DIR take.hold hand this woman Kaavo

me hâ u ulep!

CONJ 1PL.INCL PFT cross threshold

'Jump away, take Kaavo's hand and let's get out!'

All this indicates that, rather than reducing serial or complex verb constructions to other structural types of dependency through ellipsis, such constructions should be analysed as one possible configuration on a cline of various types of dependencies, going from tight co-ranking, argumentsharing predicates to asymmetric modifying predicates, or to looser asyndetic and syndetic coordination and subordination strategies. 
Complex predicates represent the highest degree of compactness and morphological economy to express syntactic and semantic specification (Aktionsart, aspect, modality, qualification, manner, direction, result, purpose, etc.) and more infrequently complementation. It is thus analogous to the cline of dependency-marking for noun determination (juxtaposed, direct or indirect marking) but in ways that are related to the verbal or predicate sphere (i.e. as complex construction vs coordination or subordination). But while the possible choice between syndetic coordination or coranking serial verbs signals some discourse strategy, the type of complementation is submitted to syntactic constraints and verb subcategorization.

\section{Conclusion: synchronic and diachronic perspectives}

Serial and complex verbs are thus a fairly underspecified structural pattern, on which are mapped a great variety of cross-linguistically common syntactic and semantic operations. Yet, their structural type is very varied, even among closely related languages. Several criteria help distinguish genuine serial constructions from verb strings with semi-grammaticalized syntactic-marking functions, as well as serial constructions from conventionalized and semantically less predictable co-lexicalizations.

In Nêlêmwa, semi-grammaticalized verb strings with argumentexpanding functions and case-role marking functions are morphosyntactic gap-fillers and never coexist with productive morphemes with a similar function. Case-roles are generally marked by prepositions (such as the instrumental marker $o$ ) or by prepositional nouns (such as the recipient marker shi); serial verbs infrequently have case-marking functions and when they do, they mostly mark peripheral participants which are lower in the semantic hierarchy. Similarly, the very productive factitive and causative prefixes $p a-, f a$ - might explain the noticeable absence of causative or resultative serial constructions in Nêlêmwa, such as I made them go or I struck him dead. Resultative notions are expressed by independent clauses (66) or by factitive derivation $(67 \mathrm{a}, \mathrm{b})$, with focus on the cause(r) rather than on the result:

$$
\begin{array}{llll}
H l i & u & \text { khiibo hom, maak. } \\
\text { 3DU PFT hit the mute one die }
\end{array}
$$

'They hit the mute one, (she) died.' (with a pause before maak) 
(67) a. I khi pa-maaxa-e.

3SG hit FACT-die.TR-3SG

'He beat him dead.' (lit. he strike cause-die-him)

b. Hla ta-pa-maaxa-e o do.

3PL pierce-FACT-die.TR-3SG CONN assagai

'They killed her with assagais.' (lit. they spear cause-die-her)

Since, in Oceanic languages, cause-result or cause-effect notions are very frequently expressed by switch-subject core-serialization, with its [sVo sVo] pattern ('I caused them they do it'), the lack of core-layer serialization in Nêlêmwa might account for this. But Mwotlap (this vol.), with its nuclear-layer causative serial construction invalidates this hypothesis. Interestingly, Mwotlap and Nêlêmwa have made different choices, Mwotlap has developed the serial construction strategy over the now decayed causative prefix, which only survives in a few unanalysable verb forms (see François, this vol.: fn. 13), while Nêlêmwa favours the morphological marking of causative notions and case-roles such as beneficiary, locative, etc.

\subsection{Grammaticalization}

A distinction must be made between grammaticalization and specialization. Grammaticalization refers to cases involving some morphophonological or categorial change, signalled for example by loss of autonomy. Specialization refers to cases which evidence synchronic functional layering of an item, either as a full lexical verb or as a syntactic operator, without any morphophonological or semantic change (only involving semantic narrowing), its change of function being context- and position-dependent.

In spite of the typological prediction that nuclear serial constructions with their VV pattern favour the erosion and drift of $\mathrm{V}_{2}$ as either a transitive morpheme or an adposition, there is only one such case of divergent evolution and grammaticalization of a verb into an applicative associative marker in Nêlêmwa: this is the case of fhe 'take', which has grammaticalized under the form ve (+inanimate), vi (+animate), while retaining its full verbal form fhe.

(68)a. I thege-vi-e ru hooc.

3SG run-ASSOC-3SG AGT horse

'The horse runs with her (on its back).' 
b. I gaa yuup-ve hî para nu na mwada. 3SG PROG crawl-ASSOC this crumb coconut LOC up there 'It (ant) crawls across with this crumb of coconut inside (the house).'

c. I $u$ fhe dume mwa taa-ve na bwa kavebu-n. 3SG PFT take down here ASS sit-ASSOC LOC on kingdom 'He brought it here to the north (and) settled with it in his kingdom.'

Cross-linguistically, a few verbs 'go, give, say, make, take' commonly grammaticalize or specialize as syntactic or case-marking functional morphemes.

There are also a few cases of a centripetal drift of $V_{2 s}$ into adverbial adjuncts, with various degrees of grammaticalization, such as loss of autonomy or delexicalization (i.e. loss of free lexemic status, Vinogradov 1990: 120) and categorial change, yet they retain their full meaning and some of their verbal properties, since they still show transitive concord (see 2.2). Finally, there are also a few cases of delexicalization without desemanticization (i.e. semantic loss), with the non-autonomous modal verbs koni 'be unable' and jara 'feel like' which behave as quasiauxiliaries; it is a common cross-linguistic tendency for verbs such as 'wish, know, be powerful, think' to grammaticalize as modality operators.

\subsection{Specialization}

On the whole, most Aktionsart or modality verbs have not undergone complete categorial change or loss of autonomy; they just evidence functional layering as full lexemes, syntactic operators or grammaticalized markers, according to context and position.

Besides, specialization or grammaticalization are contiguous phenomena with somewhat fuzzy frontiers; their identification is contextdependent, varying with the degree of semantic abstraction or narrowing. Thus, in argument-expanding serial constructions, the motion verb oxuri 'follow' tends to specialize as an adposition with the spatial reading 'along', but it is grammaticalized with the more abstract reading 'according to' (see 3.2.). Similarly, uya 'arrive' specializes as a spatio-temporal endpoint marker (meaning 'up to') in some contexts, but is fully grammaticalized as a temporal conjunction, meaning 'until' in other contexts. 
Finally, the quotative verb khabwe 'say' also evidences a cline in its complementizing functions, from an operator that preserves its lexical meaning 'say' to an utterly desemanticized complementizer.

As long as there is no clear morphophonological change, the meaning and function of such items varies from lexical and context-free (non positional) to context-bound (combinational, Vinogradov 1990: 119), with possible semantic narrowing. Its interpretation requires some contextual computation, activating or desactivating some features to retain sometimes only abstract semic features. In time, formal divergence may separate the lexical item from the syntactic operator or morpheme; but synchronic stratification of functions and meanings is one stage in the universal diachronic tendencies that Hopper (1990) labeled «layering, specialization and divergence».

Does the stratification of functions and meanings always result from some evolutionary and diachronic process? Might it not also be analysed as a synchronic strategy for economy of form and function? This would allow the mapping of several functional layers onto one form, without loss of meaning, their specific function being context-dependent.

\subsection{Co-lexicalization and idiomaticization}

Finally, serialization is not correlated with scarcity of lexical derivation in Nêlêmwa, verb compounds are numerous and favoured by verb contiguity [Vv]. They differ from serial verbs by their degree of morphological erosion and conventionalization. In Nêlêmwa, only a few verbs of posture (lie, stand, sit), and gesture (strike, pierce) have evolved as verbal prefixes in verbal compounds, whereas some languages further south on the Mainland have developed in the opposite direction with proliferating compounds and infrequent serial verbs (Ozanne-Rivierre and Rivierre, this vol.). 


\section{Orthographic conventions and abbreviations}

The main orthographic conventions used in Nêlêmwa are as follows: $\left.\left.\mathrm{c}=[\mathrm{c}] ; \mathrm{th}=\left[\mathrm{r}^{\mathrm{h}}\right] ; \mathrm{kh}=[\mathrm{x}] ; \mathrm{x}=[\mathrm{G}] ; \mathrm{vh}=[\mu] ; \mathrm{b}=\left[{ }^{\mathrm{m}} \mathrm{b}\right] ; \mathrm{d}=\left[{ }^{\mathrm{n}} \mathrm{d}\right] ; \mathrm{j}={ }^{\mathrm{W}} \mathrm{J}\right] ; \mathrm{g}={ }^{\mathrm{N}} \mathrm{g}\right] ; \mathrm{ng}$ $=[\mathrm{N}]$.

$\begin{array}{llll}\text { AGT } & \text { agent } & \text { INTENS } & \text { intensifier } \\ \text { ANAPH } & \text { anaphoric } & \text { ITER } & \text { iterative } \\ \text { ASS } & \text { assertive } & \text { LOC } & \text { locative } \\ \text { ASSOC } & \text { associative } & \text { NEG } & \text { negation } \\ \text { CLASS } & \text { classifier } & \text { PFT } & \text { perfective } \\ \text { COORD } & \text { coordinator } & \text { PONCT } & \text { punctual } \\ \text { COMP } & \text { complementizer } & \text { PROH } & \text { prohibitive } \\ \text { CONN } & \text { connector } & \text { POSS } & \text { possessive } \\ \text { CONTR } & \text { contradiction } & \text { POTENT } & \text { potential } \\ \text { DEICT } & \text { deictic } & \text { PROG } & \text { progressive } \\ \text { CONJ } & \text { dependency marker } & \text { RED } & \text { reduplication } \\ \text { DIR } & \text { directional } & \text { TOP } & \text { topicalization marker } \\ \text { DU } & \text { dual } & \text { TR } & \text { transitive } \\ \text { FACT } & \text { factitive } & \text { VIRT } & \text { virtual/irrealis } \\ \text { FR } & \text { free form } & \text { V } & \text { verb } \\ \text { FUT } & \text { future } & \text { VP } & \text { verb phrase. }\end{array}$

\section{Notes}

1. See Foley and Van Valin 1984, Crowley 1987, Durie 1997.

2. In Paamese (Crowley 1987), "core-layer serialization" is productive and associated with intransitive verbs (basic motion or posture verbs, stative, intransitive verbs), while "nuclear layer serialization" is more restricted and mostly associated with transitive verbs.

3. Various Oceanic languages display such concord on modifiers (see Bril, this vol. "Complex nuclei in Oceanic languages: contribution to an areal typology").

4. pe-xa-giik (reciprocal mkr-distributive mrk-one).

5. - (i)lî is cognate with Proto Oceanic (POc) *(aki)ni.

6. Intervocalic sandhi: sho /S/ $>$ yo $/ \mathrm{j} /$.

7. Intervocalic sandhi: khare $/ \mathrm{x} />$-xare $/ \mathrm{G} /$.

8. The general verbs of motion $o$ 'go' and $t u$ 'go down' never occur as $\mathrm{V}_{2}$ with modifying function.

9. Intervocalic sandhi $/ \mathrm{f} />/ \mathrm{v} /$ with front vowels. 
10. Intervocalic sandhi: $/ \mathrm{f} />/ \mathrm{w} /$ with back vowels.

11. Intervocalic sandhi is not obligatory, it is just frequent and does not constitute evidence of compounding. Ex.: bwa wone or bwa pone 'on the rocky land', vhaa (f) waat 'speak clearly' (vhaa 'speak' + fwaat 'be clear').
$/ \mathrm{p} /$ or $/ \mathrm{f} />[\mathrm{v}]$ ou $[\mathrm{w}]$
$/ \mathrm{t} />[\mathrm{r}],[1]$
$/ \mathrm{k} /$ or $/ \mathrm{x} />[\mathrm{x}]>\varnothing$

$/ \mathrm{fw} />[\mathrm{w}]$

$/ \mathrm{r}^{\mathrm{h}} />[\mathrm{r}]$

$/ \mathrm{c} /$ or $/ \mathrm{S} />[\mathrm{j}]$

12. Intervocalic sandhi and loss of aspiration: $/ \mathrm{r}^{\mathrm{h}} />/ \mathrm{r} /$.

13. Loss of the intervocalic velar stop and labiovelarization: $k u-(x)$ âyoot $>$ kwâyoot.

14. In post-verbal position roven 'finished entirely, completed' is an aspectual modifier verging on quantification, not a verb.

I xau tii me foro roven. 'He painted it entirely white.' 3SG ASS paint DEPEND be white finish/all

15. Intervocalic sandhi: /k/ (kîûlî) $>/ \mathrm{G} /(x \hat{u} \hat{u} l \hat{\imath})$.

16. Reduplication of cap 'run away' and intervocalic sandhi $/ \mathrm{c} />/ \mathrm{j} /$.

17. Directions, other than those expressed by some directionals 'up, down, across, away', are often lexicalized by a verb.

18. Foley states that Austronesian languages do not have ditransitive verbs except by contact with other languages ("A typology of information packaging in the clause". In Shopen, forthcoming).

19. In Nêlêmwa, most other clause-dependency markers are conjunctions or relational nouns expressing logical relationships: puxe- $t$ 'reason, origin, cause' > 'as, since'; pwaxa- $t$ 'necessity' > 'so that', etc.

20. This is evidenced by other such expressions $m u$ than 'stay, live closed up' with literal meaning (in a place), or figurative meaning (in one's thoughts).

21. In sentence initial position, it is also an explanatory conjunctive locution meaning 'that is to say'.

22. Thegela is the intransitive form and thege the form found in serial and complex constructions. 